\title{
A Religião que a Modernidade Produz: Sobre a História da Política Religiosa na França*
}

\author{
Emerson Giumbelli
}

ste texto aborda alguns aspectos do que se poderia denominar

$\triangle$ história da política religiosa na França, enfocando realidades que se distribuem entre os séculos XVI e XX e que envolvem as formas pelas quais o Estado trata a religião. Como justificar um recorte histórico tão amplo? Na verdade, a história francesa aparece aqui a propósito de uma discussão mais geral sobre o lugar e o estatuto da religião na modernidade. Pode-se situar essa discussão fazendo-se referência a uma narrativa dominante sobre a relação entre tais termos. Segundo essa narrativa, contada em termos esquemáticos, antes da "modernidade" havia uma interpenetração da "religião" com a "política", o que as tornava indissociáveis. A Reforma instaura uma cisão definitiva na cristandade, sem contudo abalar de imediato o pressuposto anterior; o resultado foram as "guerras religiosas" dos séculos XVI e XVII, disseminadas por toda a Europa. A reação a tais conflitos provocou um questionamento da indissociabilidade entre "religião" e "política", criando as condições de possibilidade para um "Estado secu-

*Este texto é uma versão, bastante alterada, de trabalho apresentado na $22^{a}$ Reunião da Associação Brasileira de Antropologia - ABA (Brasília, 2000). Agradeço os comentários dos colegas do GT "Teorias Etnográficas de Segmentaridade”, assim como aos pareceristas de Dados.

DADOS - Revista de Ciências Sociais, Rio de Janeiro, Vol. 44, nำ 4, 2001, pp. 807 a 840. 
lar". Nesse sentido, o Estado plenamente "moderno" é aquele conduzido sob uma exigência que declara desconsiderar a "religião": não só procura manter-se longe da influência das instituições religiosas, como também não interfere na existência delas.

A história que vou contar aponta para uma outra perspectiva. Partindo de uma estratégia nominalista, a "religião" aparece ela mesma como uma categoria moderna. Quanto ao aspecto conceitual, existe uma série de estudos que insistem nas transformações ocorridas a partir do século XIV, e especialmente dos XVI e XVII, na noção de "religião"1. Admitindo que as realidades que essa noção pretendia designar não eram evidentemente novas, salienta-se no entanto que se forjaram significados e estatutos originais para a categoria "religião". Várias gerações de pensadores contribuíram com formulações que provocaram não a desconsideração dessa noção, mas uma reconceituação que, paradoxalmente (pois tudo parecia apontar para seu desaparecimento no plano das realidades), a consolida como uma categoria relevante para a ordenação do mundo. Um outro aspecto da problemática é a dimensão política. Nesse caso, o que se pode argumentar é que, analogamente ao que ocorre no plano conceitual, longe de ser simplesmente desconsiderada, a "religião" assume sentidos que a colocam, de maneira original, na condição de critério significativo de ordenação social na perspectiva do Estado moderno. Ou seja, a dissociabilidade entre Estado e religião não implica necessariamente desinteresse do primeiro pela segunda. É com esse olhar que procuro abordar a trajetória da política religiosa na França.

Mas por que a França? É fácil observar que a França ocupa um lugar paradigmático nas discussões sobre religião e modernidade. Trata-se, afinal, do palco das mais sérias e ameaçadoras "guerras de religião" no panorama europeu do século XVI; a resolução desses conflitos, no limiar do século XVII, marca, para muitos, exatamente a abertura para uma "política secular" e para a "liberdade religiosa". O termo que condensa os rumos tomados pela sociedade francesa, em um caso no qual a centralidade do Estado se tornou particularmente forte, é "laicização". Com ele, pretende-se apontar para uma dupla característica dessa sociedade, conquistada em meio a vicissitudes históricas que às vezes pareciam contrariá-la. De um lado, a "separação jurídica" entre Estado e religião, consolidada em 1905 e inscrita nas leis constitucionais francesas posteriores; de outro, a inclusão da religião entre os direitos civis, base da idéia de "liberdade religiosa", legal-

\section{8}


A Religião que a Modernidade Produz...

mente estabelecida com a primeira Declaração Universal dos Direitos do Homem e do Cidadão de 1789. A partir disso, apesar da singularidade de sua história (singularidade não raramente elevada a atributo distintivo de uma certa identidade nacional), a França assumiria o valor de modelo tanto do que teriam sido as "guerras religiosas", quanto do que constituiria uma "política secular" compromissada com a "liberdade religiosa".

Valho-me então desse estatuto paradigmático como motivação para a escolha do caso francês em uma discussão com preocupações mais amplas. Buscando colocar em primeiro plano exatamente as tais "vicissitudes históricas", o argumento geral insiste na idéia de que "resolução de conflitos confessionais", "política secular" e "liberdade religiosa" são produzidas no bojo de um processo no qual o Estado promove várias e sucessivas formas de reconhecimento da "religião". Essas formas se concentram, em um primeiro período (do século XVI ao XVIII), em torno do estatuto dos protestantes em um reino que considera os súditos a partir de seu vínculo privilegiado com a Igreja Católica. Em seguida, no século XIX, deslocam-se em direção a um conjunto de instituições eclesiais, que se apresentam nesse momento atreladas ao Estado. Enfim, reiteram-se mesmo no contexto inaugurado pela "lei de separação", do início do século XX, de um modo que fica especialmente claro agora, quando o "islamismo" e as "seitas" conquistaram o foco das atenções oficiais em termos de questões religiosas. É tendo em vista o acompanhamento dessas formas mutantes de reconhecimento da religião pelo Estado francês que se justifica o recorte histórico adotado aqui. Começo, portanto, no século XVI propondo uma reconsideração das "guerras de religião", que aposta no argumento de que a "religião", por si só, não sustenta os conflitos cobertos por essa designação - passo preliminar para demonstrar que é da perspectiva do Estado que, após a resolução desses conflitos, a categoria "religião", concebida como algo circunscrito em relação a outros domínios, ganha maior consistência e utilidade.

Resta ainda fazer um último esclarecimento preliminar. Com exceção do período atual, os dados sobre os quais baseio meus argumentos provêm de fontes secundárias. Recorro a um conjunto de textos, de natureza diversa, que enfocam algum período do espectro temporal coberto por minha discussão. Entretanto, não tive em nenhum momento a intenção de realizar um levantamento exaustivo da bibliografia histórica, nem de contemplar o maior número possível de fon- 
tes. Meu objetivo não é realizar um balanço bibliográfico sobre a história da política religiosa na França entre os séculos XVI e XX, localizando pontos de consenso e de controvérsia. O que procuro fazer consiste em ordenar - sob uma forma que, até onde sei, é original - determinados dados e conclusões presentes nessas fontes, observando-os de acordo com outra perspectiva e inserindo-os em um quadro de outras dimensões. Assim, apesar da abordagem histórica, as questões que este artigo procura articular são de natureza sociológica e antropológica, uma vez que se relacionam, como já se assinalou, ao estatuto e ao lugar da religião na modernidade, tomando a França como caso privilegiado.

\section{GUERRAS COM RELIGIÃO}

Fala-se em "guerras de religião" para se fazer referência a uma série intermitente de conflitos ocorridos na França, entre os anos de 1559 e 1598. A expressão "guerras de religião" supõe que esses conflitos envolvessem como móvel e/ou como vetor de repartição dos adversários questões e princípios religiosos - mais especificamente, a oposição entre católicos e protestantes. Nesse sentido, seriam apenas a manifestação local de tensões presentes em todo o continente nos séculos XVI e XVII, cujo resultado de maiores proporções foi a Guerra dos Trinta Anos (1618-1648), da qual participaram diversas nações européias. Posteriormente, esse conjunto de tensões e conflitos serviria comumente como evidência no quadro de argumentos ideológicos dedicados a mostrar de que maneira a política religiosamente orientada jamais conduziria à paz e como a religião politicamente motivada estaria sempre associada ao fanatismo e à intolerância. Limito-me ao caso da França, o mais drástico em se tratando de uma situação circunscrita aos limites nacionais, propondo que seria mais adequado considerar os conflitos do século XVI como o produto de um conjunto de diversas variáveis, tornando impossível avaliar o papel da religião fora de sua inserção nesse conjunto mais amplo de vetores, motivações e divisores.

O século XVI representa um período crucial na consolidação de um Estado-nação francês que procura acontecer em torno do fortalecimento de seus monarcas e da anexação de porções territoriais significativas, tendências que se afirmarão definitivamente no século seguinte. Por isso, a lealdade dos súditos e o poderio militar adquirem uma importância de primeiro plano. Do ponto de vista desse proces- 
so, a "religião" tem um lugar fundamental. Primeiro, em função da natureza singular da monarquia francesa, cujo vínculo com o cristianismo, que tinha em Roma o seu centro, era para muitos consubstancial. Daí a natureza verdadeiramente sacerdotal de que ficava investida a figura do rei na França no século XVI. Mas, além desse, havia ainda outro aspecto, este menos ligado a uma legitimação tradicional. A unidade religiosa, sob uma única confissão, surge como desejável e mesmo como ideal no momento em que a consolidação de um poder central depende da quebra das pequenas e múltiplas lealdades que sustentavam a sociedade medieval; a "religião" reconfigurando-se como fator de uma nova coesão social. Para o Estado que então se forjava, "assegurar-se da conduta futura de um indivíduo dependia da verificação que demonstrasse que ele havia assimilado as crenças corretas fundamentais" (Despland, 1979:312). A promessa de proteger a Igreja e de extirpar a heresia, parte integral do juramento que os monarcas franceses faziam ao ocupar o trono, parecia merecer, agora mais do que antes, empenho especial na sua aplicação, uma vez que estava imbuída de uma dimensão propriamente política.

Diante desse projeto, no qual a unidade religiosa se vinculava à exigência de unidade política, o surgimento e a expansão do protestantismo não poderiam deixar de representar uma ameaça. Não exatamente porque o protestantismo trouxesse consigo reivindicações de "liberdade religiosa" ou propostas de "política secular" segundo feições modernas. Bastava observar os lugares onde havia ganho posição dominante para perceber que ortodoxia religiosa e atrelamento com o poder estatal não eram apanágio do catolicismo. O desafio colocado pelo protestantismo vinha, além do fato de ter se tornado dominante em certas regiões do estrangeiro, do êxito de sua penetração na sociedade francesa. Por volta de 1660, esse êxito é inegável. Impulsionado por estratégias missionárias que tinham seu ponto de irradiação em Genebra, uma república calvinista, expressa-se na presença de congregações zeladas por pastores; em rituais celebrados em centenas de igrejas concentradas nas regiões central e sul da França; na realização de sínodos que reúnem representantes de várias comunidades, o principal dos quais tendo já definido a confissão de fé que identificaria os protestantes franceses. Entre os convertidos, destacam-se vários nobres, que junto com a adesão confessional trazem legitimidade e proteção à nova religião. 


\section{Emerson Giumbelli}

Nesse quadro, o que caracteriza a política religiosa francesa no período em que ocorrem as "guerras de religião" é a tentativa de instaurar a coexistência de católicos e protestantes sob o mesmo soberano sem, porém, abdicar do ideal de unidade religiosa. Após os esforços, mais ou menos firmes conforme a época, durante os reinados de Francisco I (1515-1547) e Henrique II (1547-1559) no sentido de "extirpar a heresia", quase todos os sucessivos éditos entre 1561 e 1598 insistirão na alternativa da coexistência. Como se operava essa conciliação aparentemente impossível entre diversidade confessional e unidade religiosa? Vários desses éditos são, na verdade, o produto de um compromisso operado no interior de uma conjuntura caracterizada pela resistência política e militar dos protestantes. Em alguns casos, no entanto, o édito traduzia um projeto postergado de unidade religiosa, nutrido pelo soberano, que impunha transitoriamente a convivência entre as partes conflitantes. Essas fórmulas engendraram para a França uma situação singular na Europa da segunda metade do século XVI (Baubérot, 1993; Poulat, 1987; Wanegffelen, 1998). Com a definição legal e reconhecida da coexistência entre católicos e protestantes, chegava-se a uma solução que a distinguia tanto da Inglaterra, onde se consolidara uma Igreja nacional (com a punição dos não-conformistas), quanto dos domínios do Império Germânico, onde dominava o princípio que convertia a escolha do soberano na "religião do território" (à qual os súditos deveriam aderir).

Vê-se então que o catolicismo, confissão à qual um monarca francês jamais deixou de jurar obediência, nem sempre foi considerado, seja por motivos estratégicos, seja por não corresponder perfeitamente ao ideal cultivado pelo soberano, a única possibilidade quando se tratava de assegurar a fidelidade dos súditos a um poder central. O mesmo pode-se dizer em relação ao contexto das relações internacionais no qual se inseria o projeto nacional francês. O vínculo com o catolicismo predispunha os monarcas franceses a certas alianças e oposições: espanhóis, de um lado; ingleses e alguns domínios germânicos, de outro. Mas isso não significa que não ocorressem situações que contrariavam ou revertiam esse conjunto de posições. Interesses geopolíticos, especialmente em torno da região dos Países Baixos, levariam a confrontos entre a França e a Espanha. Em outros momentos, novamente a Espanha representaria um perigo ao aparecer como aliada não do poder central, mas de facções na França cuja ação de algum modo co-

\section{2}


locava em risco a afirmação daquele poder. As afinidades religiosas, portanto, não definiam vínculos ou rupturas incondicionais.

Para entender o que se passa nas chamadas "guerras de religião", outro elemento é ainda importante. Catolicismo e protestantismo identificam "confissões religiosas", estruturadas segundo suas respectivas organizações eclesiais. Consideradas do ponto de vista dessa dimensão, há uma evidente assimetria entre elas. O catolicismo goza da proteção estatal, o que também significa que o monarca possui poderes sobre a Igreja, legitimados por uma concordata com a Santa Sé (de 1516), que lhe concede a prerrogativa de nomeação dos bispos. Já o protestantismo, no seio do qual os calvinistas representam larga maioria, desenvolve-se na França à revelia do poder central e em estreita conexão com suas origens estrangeiras. No entanto, catolicismo e protestantismo identificam também "partidos", ou seja, forças políticas e militares paralelas e contrapostas. "Huguenote", termo que se consagrou para designar os calvinistas na França, fazia referência direta exatamente a essa dimensão da sua existência. Assim, por volta de 1560, os calvinistas não apenas estão bem organizados em suas atividades religiosas, mas também, enquanto "huguenotes", articulam um feixe de vetores políticos: "assembléias políticas", além de organizarem as reivindicações de uma minoria religiosa, alimentam a autonomia de regiões e cidades e ressonam a força de interesses políticos e militares. Enfim, ameaçam com o recurso possível a potências protestantes estrangeiras.

Dito isso, é necessário bem precisar a relação entre as dimensões religiosas e políticas. Não existe continuidade entre elas, como se estivéssemos diante de uma religião militar e politicamente organizada; também não se trata de duas estruturas sobrepostas ou homólogas, diferenciadas apenas por seu plano de ação. $O$ fato de o protestantismo ter adquirido uma dimensão política ou militar deve ser considerado sobretudo a partir da forma pela qual se difundiu na sociedade francesa. Recorro, nesse caso, às contribuições de Vernard, que se refere a dois "sistemas de organização" (no interior dos quais se estruturam os componentes propriamente eclesiais): "o sistema 'feudal', ou, melhor, nobiliário, assentado sobre uma pirâmide de clientelas [...]; e um sistema municipal, fundado sobre as cidades onde o poder é detido pelos reformados" (1988:258). Isso quer dizer que, em um território cujo poder central está vinculado ao catolicismo, o protestantismo expande-se associado a solidariedades "feudais" e a redes que alimen- 
tam autonomias locais. Seu relativo alijamento da "grande política" é contrabalançado por sua influência junto à "pequena política".

Quanto ao catolicismo, vários elementos devem ser levados em conta. O contexto mais geral é dado pela realização do Concílio de Trento, selo e bastião da Contra-Reforma. Ainda no plano externo, a monarquia espanhola apresenta-se como a defensora menos reticente de uma política de consagração do catolicismo. No plano interno, lembremos em primeiro lugar que o clero, além de controlar publicações e sistemas educacionais, constitui um dos três "estados" em que se organiza a sociedade francesa. Mas isso não fazia da Igreja Católica na França um corpo homogêneo, uma vez que a diversidade se expressava seja na ordem institucional, seja na ordem devocional. E, como já se notou, havia o atrelamento com a monarquia, apontando para a consolidação do que ficou conhecido como "galicanismo". As implicações políticas desse sistema eram óbvias. Segundo Holt (1995:13), Francisco I e Henrique II utilizaram sua prerrogativa de nomeação de bispos para preencher postos episcopais com clientes, parentes e aliados. Na verdade, quando se observa as instâncias político e militar, pouco diferenciava o catolicismo do protestantismo. Assim como o alto clero estava sujeito aos interesses do poder central, em contextos mais circunscritos ocorriam condições que possibilitavam a formação de "partidos" baseados em clientelas nobiliárquicas e localismos políticos.

Creio já termos os elementos para reconsiderarmos as chamadas "guerras de religião" no sentido acima apontado. Elas se desenrolam, como se disse, em um quadro no qual o poder central opta, não sem hesitações e recuos, por uma política que garantiria a coexistência de católicos e protestantes. Diante do poder central estão os "partidos", cujas recomposições e alianças - envolvendo dinâmicas internas, relações com o poder central e apelos a forças estrangeiras — apontam para a feição que vão assumindo os conflitos. Embora em vários momentos a participação popular constitua elemento decisivo e inegável, o vetor principal permanece sendo as investidas militares e assassinatos pessoais agenciados pelos nobres que comandam os "partidos" e pelos detentores do poder central. Em termos gerais, os embates seguem um mesmo padrão: "uma campanha militar na qual nenhum dos lados conseguiria derrotar definitivamente o outro seguida por uma paz que a Coroa era incapaz de administrar ou impor totalmente" (idem:56). Note-se que crises econômicas e agitações sociais

\section{4}


A Religião que a Modernidade Produz...

tornam o período (1559-1598) particularmente conturbado. Além disso, o trono francês parece amaldiçoado após a morte de Henrique II: depois de três de seus filhos o ocuparem, ele passa finalmente a Henrique $\mathrm{IV}$, que inaugura uma outra dinastia monárquica. $\mathrm{O}$ Édito de Nantes, outorgado em seu reinado, marca o fim das "guerras de religião". Quanto ao que veio antes, sugiro que distingamos três momentos, na medida em que eles identificam mudanças nas configurações de forças e alianças entre os vários personagens em cena. A idéia é avaliar o peso e o lugar que teve a "religião" em cada um desses perío$\operatorname{dos}^{2}$.

O primeiro período de conflitos tem como marcos a morte inesperada de Henrique II, em 1559, e os massacres de São Bartolomeu, em 1572, resultado de tramas palacianas e ódios populares cujo saldo é a morte de cerca de 10 mil protestantes em várias cidades da França. Henrique II é sucedido por Francisco II, seu filho, cujo falecimento prematuro dá lugar à regência de Catarina de Médicis, interrompida pela maioridade de Carlos IX (que ocorre em 1563). Os conflitos que se desenrolam nesse primeiro período têm como protagonistas principais os "partidos religiosos". São os "huguenotes" que tomam a iniciativa do enfrentamento violento em 1560, 1563 e 1567; a reação católica é firme e eficaz todas as vezes. Mas o que se assiste não é ao embate de duas "religiões", mas a "religião" servindo para identificar e compor grupos que se opõem em termos de clientelas políticas (os massacres de São Bartolomeu ganhando estatuto de vendetta para os Guise, líderes dos católicos) e pertencimentos locais (como fica evidente nos conflitos de 1563, que opõem uma Paris católica a uma Orleans protestante). Essa luta de facções e de regiões, no entanto, não ocorre a despeito do poder central; ao contrário, os "partidos" procuram agir tendo como referência os movimentos do monarca, buscando preservar ou alterar (a seu favor) uma certa correlação de forças. Isso ocorre em 1560, quando os protestantes tentam, à força, manter o rei ao seu lado; em 1567, quando novamente os protestantes reagem diante do que interpretam como um indício de aliança entre os monarcas franceses e espanhóis; depois de 1570, quando os católicos temem que Carlos IX se alie com a Inglaterra contra a Espanha. Outra prova da importância do poder central é o êxito momentâneo de vários éditos $(1562,1563$, $1568,1570)$, que impõem a paz e prescrevem a convivência de católicos e protestantes. 


\section{Emerson Giumbelli}

Essa importância decresce significativamente no segundo período, durante o reinado de Henrique III, que substitui seu irmão em 1574. A obnubilação do poder central reflete o fortalecimento dos partidos religiosos e a divisão da própria família real. Os protestantes reúnem forças políticas e militares consideráveis e mobilizam aliados estrangeiros; além disso, para aumentar seu poder de pressão, contam com a ajuda dos "malcontents", grupo que orbitava em torno do irmão do rei visando apressar a sucessão do trono. Os católicos sofisticam sua organização, formando coletivos que ficaram conhecidos como as "ligas", ganhando maior autonomia em relação ao poder central. O monarca vê-se obrigado, de acordo com as circunstâncias, a atender às demandas de um ou outro grupo, outorgando éditos que ora inovavam em concessões para os protestantes (1576), ora ratificavam antigas restrições (1577 e 1580). Ao mesmo tempo, Henrique III, parecendo replicar as estruturas dos "partidos", constitui em torno de si uma clientela de fiéis (fundando a Ordem do Espírito Santo) e de políticos locais (os "mignons"). Ou seja, nesse período, o monarca, os católicos e os protestantes tendem a mobilizar redes religiosas, políticas e familiares, paralelas até certo ponto, pois afinal o poder central não é jamais dissolvido.

A morte do irmão do rei em 1584 provoca uma reviravolta na situação. Por uma regra dinástica, Henrique III não tendo filhos, o trono passaria a Henrique de Navarra, então o principal chefe protestante. Diante do perigo de ver a monarquia encabeçada por um "herético", a reação dos católicos toma caminhos inesperados. Sua mobilização, imediata, faz-se através das "ligas", coletivos que juntavam demonstrações ostensivas (e bastante populares) de devoção e alternativas de organização política. Novamente, estavam envolvidas clientelas "feudais", o domínio da política local e a invocação ao apoio espanhol. Tramava-se a defesa da causa de outros pretendentes à sucessão do trono; mas, ao mesmo tempo, como demonstra o caso de Paris, tentou-se a instauração de governos (baseados em conselhos locais) cujo funcionamento e legitimidade nada mais deviam ao poder central. A experiência (1588-1589) provocou uma curiosa aliança, com repercussões militares (Paris foi sitiada), capaz de colocar lado a lado o monarca, o partido protestante e os católicos royalistes. Vê-se como nesse momento o suporte ao poder central recorta as próprias divisões religiosas que pareciam ameaçá-lo. Henrique III é assassinado em 1589 e a situação só ganha uma direção clara após a abjuração de Henrique

\section{6}


de Navarra, ato que o traz de volta ao catolicismo. Novamente católico, Henrique de Navarra reúne as condições para ser reconhecido rei. Aos poucos, mediante acordos ou ações militares, ele domina as regiões rebeldes ao poder central; em 1598, outorga o édito que, em virtude de seu êxito, serve de marco para o fim das "guerras de religião".

Não é difícil, depois desta síntese dos conflitos, perceber quão pouco adequada se tornou essa expressão. Não se pode, evidentemente, negar que questões religiosas estavam em jogo e que os enfrentamentos se encontravam perpassados por uma concepção religiosa do mundo. Contudo, por um lado, os conflitos raramente foram apenas "religiosos"; ao contrário, envolviam elementos e vetores que remetiam a dimensões propriamente políticas (o balanço entre poderes locais e faccionais e poderes centrais), em relação às quais os componentes religiosos ora funcionavam como aglutinadores ou catalisadores, ora sofriam uma relativização de seu potencial identificatório. Por outro lado, e simultaneamente, a própria "religião" jamais nesse momento se caracterizou como "puramente religiosa": a forma como catolicismo e protestantismo se organizavam torna-os indissociavelmente ligados aos projetos de consolidação do poder central, às margens de autonomia do poder local, às solidariedades e lealdades que existiam (e aos seus rearranjos) no tecido social. Essas observações são aplicáveis a muitos dos "conflitos religiosos" que assistimos hoje, mas não se deve perder de vista a diferença substancial em relação ao século XVI francês: naquele contexto, a religião não se apresentava em um sentido moderno, ou seja, como um domínio específico da realidade. Enfim, sem dúvida, a religião fez parte dos conflitos que ocorreram na segunda metade do século XVI na França; mas de tal modo que apenas por respeito ao uso poderemos continuar a nos referir às "guerras de religião".

\section{UMA POLÍTICA DA RELIGIÃO}

Na medida em que impõe a coexistência entre católicos e protestantes, o Édito de 1598 junta-se a outros anteriores, de menor êxito, para confirmar a distinção entre "unidade religiosa" e "unidade política". A partir disso, vários autores falaram na predominância ou na preeminência de uma "razão de Estado". Tratar-se-ia, para Christin, de uma "autonomização da razão política": 
Emerson Giumbelli

“[...] a emergência de um espaço (parcialmente autônomo) no qual as questões políticas são pensadas sob a exigência de serem distinguidas, isoladas, preservadas dos problemas confessionais. O campo político-jurídico foi assim pouco a pouco definido [...] como o lugar onde reconstruir (à escala de uma vila, de uma cidade ou de um reino) o interesse geral, o bem comum, que a religião não podia mais encarnar" (1997:205).

Seu estudo - no que concerne à França, privilegia o período inaugurado pelos primeiros éditos de coexistência (1562 e 1563) - enfatiza que a lógica, a linguagem e os mecanismos de produção da paz seriam antes jurídicos do que religiosos. O Édito de 1598 iria no mesmo sentido. Como seu preâmbulo indica, trata-se da "união, concórdia, tranqüilidade e repouso" dos súditos reais que dependem do "restabelecimento desse Estado em sua primeira grandeza, opulência e força" (apud Wanegffelen, 1998:262). Os primeiros artigos do édito decretam a anistia de crimes e violências cometidos pelo "fato da religião"; outros, mais adiante, exigem que predicadores católicos e protestantes se dediquem à instrução e à edificação dos próprios fiéis, evitando confrontos diretos e contribuindo ativamente para a pacificação.

No entanto, falar da autonomização da "razão de Estado" em relação à religião não parece totalmente adequado para descrever o que se passa efetivamente. Uma coisa é a consolidação do poder central e a conseqüente subordinação de forças locais e faccionais, o que só pode ocorrer nesse momento através do impedimento de novas "guerras de religião". Mas isso não quer dizer que a "religião" esteja ausente do discurso que fundamenta as intervenções que partem do poder central. Ao contrário, pode-se dizer que é exatamente nesse discurso que a "religião" adquire um estatuto próprio e específico, que serve para distingui-la, enquanto princípio de organização social, de outros vetores. Afinal, os Éditos de 1561 e 1562 e de 1598 reafirmam o estatuto privilegiado do catolicismo, o que representa, sobretudo, uma forma de manter o ideal de uma nação religiosamente homogênea. Mas, diante da impossibilidade de concretizar imediatamente esse ideal, procura-se garantir aos protestantes certas condições para o exercício de sua religião. O resultado é o reconhecimento político de identidades propriamente religiosas. Ou seja, os súditos passam a ser legalmente considerados por suas adesões confessionais. No contexto de 1598, essa solução proporciona a paz. Em 1561 e 1562, contudo, ela pode ter contribuído, ao validar (e portanto reforçar e cristalizar)

\section{8}


identidades religiosas em uma configuração na qual os antagonismos se tornaram incontroláveis, para detonar conflitos violentos.

Vejamos então as definições do Édito de 1598, comumente celebrado, como muitas vezes foi o caso nas recentes comemorações de seu quarto centenário, enquanto uma espécie de precursor da instauração de direitos civis e religiosos para uma minoria. A análise de seus principais artigos aponta para um quadro algo diferente. No plano da vida religiosa, os reformados conquistam uma liberdade que afirma ao mesmo tempo sua subordinação aos católicos. Esta subordinação se estabelece, em primeiro lugar, pela distinção entre "consciência" e "culto". Reconhece-se "liberdade de consciência" aos reformados, enunciada, entretanto, em uma formulação negativa: que eles não sejam constrangidos "a fazer qualquer coisa pelo fato da religião contra sua consciência" (idem:267). Por isso, estão dispensados de obrigações de reverência e de contribuição material ao catolicismo, assim como protegidos contra o proselitismo forçado dos católicos; mas ficam sujeitos à censura de suas publicações. Quanto ao culto, o édito, ao mesmo tempo que prevê subvenções à manutenção de templos e pastores, além de permitir a coleta de recursos para fins religiosos, estipula cuidadosamente as condições de sua realização. Eram estabelecidas três categorias de exercício religioso. Uma primeira reconhece aos protestantes o direito de cultos públicos nas cidades onde eles já existiam em um determinado momento ou haviam sido permitidos por outros éditos; uma segunda concede para cada circunscrição judiciária lugares de culto suplementares, desde que se localizem além dos muros das cidades. Ora, essas regras genéricas, elas mesmas já limitadas por certas exigências, sofriam ainda de uma série de exceções (cultos públicos protestantes eram proibidos, por exemplo, na corte, em Paris e em seus arredores, nas cidades episcopais e eclesiásticas e nos lugares excluídos em acordos específicos com autoridades locais). A terceira categoria previa a possibilidade, onde os cultos públicos eram interditos, de realização de cultos domésticos, somente na residência de nobres, em condições que variavam segundo sua posição.

Essas restrições se tornam logo compreensíveis diante do tratamento reservado ao catolicismo pelo mesmo édito. Este cuida de restabelecer o culto católico em todo o território do reino (em algumas regiões, o calvinismo havia se tornado exclusivo), restituindo os benefícios e os bens eclesiásticos. Além disso, o preâmbulo anuncia a esperança 


\section{Emerson Giumbelli}

de que os reformados - ou, para usar o termo do documento, "aqueles da religião pretensamente reformada" - venham algum dia a reunir-se aos católicos ${ }^{3}$. Em 1561 e 1562, antes de recorrer à política dos éditos de pacificação, a regente Catarina de Médicis havia se empenhado em um projeto de conciliação doutrinária, promovendo colóquios entre católicos e calvinistas. No Édito de 1598, volta a se manifestar esse ideal da unidade religiosa - pelo qual Henrique IV se empenhou durante seu reinado, de um modo, é verdade, que não condizia precisamente com o plano da Igreja Católica ${ }^{4}$ - cuja realização imediata a "paz pública" impede, mas que serve para hierarquizar católicos e protestantes nessa nação agora pacificada. A "liberdade" de que desfrutam os huguenotes se insere, portanto, nesse movimento de subordinação. Por isso, o problema que o édito se coloca consiste, como formula Holt (1995:164), em integrar os huguenotes, considerados enquanto grupo, em um Estado católico.

O Édito de Nantes implicou também o reconhecimento dos reformados como uma minoria no plano civil, garantindo-lhes a um só tempo inserção e distinção como súditos do rei. Graças ao édito, os reformados gozam dos mesmos direitos civis, mesmo tratamento fiscal e de igual acesso a serviços educacionais, hospitalares e assistenciais, assim como a funções públicas. Essa inclusão se estende ao pagamento do dízimo e à obrigação de descanso durante os feriados católicos, consideradas exigências políticas, e não religiosas. Uma das únicas restrições nesse terreno era a proibição de manter escolas onde não houvesse culto público (nesse caso, permitia-se preceptores domésti$\cos$ ). Por outro lado, pelo menos duas medidas distinguem os reformados do resto da população. As causas civis e criminais que envolvessem protestantes seriam julgadas em condições especiais (câmaras nos parlamentos com a participação obrigatória de juízes protestantes). Além disso, apesar da proibição de associações e ligas políticas, garantiu-se a presença de um representante huguenote junto à corte. Por fim, cerca de 150 lugares foram confirmados como uma espécie de protetorado sob a guarda protestante, metade dos quais abrigando tropas pagas pelo rei. Ou seja, ao mesmo tempo que se procurava dar igualdade civil e neutralizar politicamente os protestantes, mantinham-se para eles prerrogativas judiciárias e militares diferenciadas.

As condições que circunscreviam o culto protestante e que distinguia seus praticantes em certos aspectos de sua vida civil e coletiva trans- 
formavam, segundo Wanegffelen (1998:31), os reformados em uma "quase ordem", ao lado das outras três que constituíam a sociedade francesa. Holt (1995:166) nota que, ao permitir que os huguenotes mantivessem posições militares, Henrique IV endossava a situação de "um Estado dentro do Estado". O ponto fundamental, a meu ver, consiste no seguinte: declarar-se "reformado" no interior de um quadro legal como o prescrito pelo Édito de Nantes significava não apenas pertencer a uma minoria religiosa, desprivilegiada diante da religião do monarca, mas também estar submetido a regras específicas no plano civil. Esse dispositivo de distinção se completa com o recenseamento realizado no mesmo ano de 1598, que incidiu sobre o número de lugares de culto, de pastores, de famílias e de indivíduos pertencentes à "religião pretensamente reformada" (Livet, 1996:31). A possibilidade de constituir estatísticas sobre os reformados deve ser tomada como indício direto de sua transformação em uma categoria que foi integrada à lógica jurídica com a qual opera a monarquia francesa.

O que acontece depois? ${ }^{5}$ O Édito de 1598 será revogado por outro, de 1685, destinado a proibir "qualquer exercício público da religião pretensamente reformada (RPR)". O preâmbulo serve-se, como justificativa, do ideal de reunificação que movia Henrique IV, confirmando as interpretações que enfatizam a lógica da unidade presente no Édito de Nantes. Ademais, continua o documento de 1685, os éditos referentes aos protestantes haviam se tornado inúteis, pois "a melhor e maior parte de nossos súditos da dita RPR abraçaram o catolicismo" (apud Garrison, 1985:11). Atrás da ilusão ou do cinismo de tal afirmação, algo há de bastante verdadeiro, sem o que não se compreende como se pôde pretender decretar o desaparecimento de uma religião que em 1600 reunia mais de um milhão de pessoas, $6 \%$ da população: pois se constituiu na França do século XVII uma máquina de eliminação do protestantismo, que consistiu basicamente na radicalização da subordinação religiosa ao catolicismo e na substituição dos mecanismos de distinção civil que acabamos de notar por outros bem menos ambivalentes. Tudo se passa como se o reconhecimento que os reformados haviam conquistado ao final do século XVI fosse utilizado agora em seu desfavor. Como se as distinções que haviam propiciado sua existência civil e religiosa contribuíssem agora para melhor focalizar o alvo de uma política de desaparecimento. 


\section{Emerson Giumbelli}

O momento decisivo para a montagem dessa política parece ter sido o desfecho de uma série de revoltas armadas que mobilizaram partidários e regiões huguenotes, ocorridas primeiro entre 1611 e 1616 e depois entre 1621 e 1629. Alarmados com o assassinato de Henrique IV e com certas medidas de Luís XIII, os huguenotes retornaram a movimentar sua máquina política e militar em uma configuração que os opunha às forças reais. Ao final daquele período, vencidos e com suas cidades dominadas, os protestantes vêem-se obrigados a aceitar um acordo que determina o fim dos protetorados militares e inviabiliza definitivamente a realização de assembléias políticas. Nas duas décadas seguintes, outras precauções são tomadas com a justificativa da necessidade de neutralizar um perigo político (por exemplo, a ruptura de relações com o exterior e a vigilância de assembléias religiosas). Finalmente, depois de 1656, sucedem-se medidas que atacam os reformados por vários flancos.

Interpretações restritivas dos dispositivos do Édito de Nantes instrumentalizam a demolição de templos e a proibição de cultos; os sínodos passam a ser restritos e vigiados; procura-se cercear as manifestações públicas de protestantismo; várias proibições se juntam para impedir o seu crescimento religioso. A contrapartida dessas medidas é o favorecimento explícito ao catolicismo, aumentando-se os incentivos a conversões, punindo-se severamente os relapsos, obrigando-se reverências, patrocinando-se a refutação erudita. Ou seja, trata de se marcar hiperbolicamente a hierarquia entre as duas religiões, sem ceder, ao menos retoricamente, ao recurso das "conversões forçadas". Mesmo quando um huguenote era obrigado a hospedar soldados em sua casa (medida por muitos sofrida entre 1683 e 1685), se ocorria uma conversão, ela deveria estar registrada por uma declaração supostamente voluntária. Quanto à vida civil, as condições especiais de tratamento judiciário desaparecem progressivamente. Em seu lugar, disseminam-se as exclusões civis, que atingem funções políticas e públicas em seus vários escalões, bem como requisitos para regularizações profissionais e capacidades jurídicas (quanto a heranças etc.). Às distinções negativas no plano religioso, portanto, juntam-se outras no plano civil. Mesmo assim, os pastores protestantes continuaram a poder oficiar batismos e casamentos que tinham validade oficial, e medidas cada vez mais severas pretendiam impedir que os huguenotes buscassem o exílio. O resultado foram as conversões massivas que passaram a ocorrer no período em torno do Édito de 1685. 
O Édito de 1685 - celebrado em um mural no palácio de Versalhes, em que vemos a "Heresia" derrotada pela "Religião" — ordena a demolição de todos os templos protestantes e impede qualquer culto doméstico, além de proibir pastores não convertidos de permanecerem no reino (enquanto os convertidos são premiados); todas as crianças devem ser batizadas no rito católico e educadas em escolas católicas; incentiva-se a volta dos expatriados e interdita-se o exílio. Ponto mais curioso do Édito: cria-se uma nova categoria de pessoas, as não ainda convertidas. Ou seja, não se oferece outra alternativa aos protestantes que "ainda" não voltaram ao catolicismo que a de se converter, embora não sejam forçados a isso. Nesse ínterim, devem se casar e batizar seus filhos na Igreja Católica, além de se submeter à extrema-unção antes de morrer. Em 1715, outro édito declara "convertidos" todos os ex-protestantes que permaneceram na França. Este seria o ponto final de uma assimilação à "verdadeira religião"?

As coisas eram mais complicadas, como o próprio clero católico admitia ao se preocupar com maneiras de "autenticar" o catolicismo dos "novos convertidos", especialmente dos que pretendiam se casar. Pois, na verdade, a "conversão" passou freqüentemente a ser uma estratégia para pessoas que preferiram não seguir a massa de exilados, integrando-se às formas de resistência através das quais o protestantismo mantinha suas práticas e suas comunidades (assembléias clandestinas, cultos domésticos etc.). Durante o século XVIII, a camuflagem dá lugar à presença aberta. Já na década de 1720, ocorre uma recomposição das instituições eclesiais; na de 1740, a causa protestante ganha apoio em vários setores; por volta da década de 1760, implanta-se uma política de tolerância de facto, a ponto de a categoria "novo convertido", cujos assuntos eram atribuídos a um órgão específico da burocracia governamental, servir efetivamente para designar os protestantes - o que demonstra o fracasso do dispositivo de assimilação montado desde o século anterior, algo que o próprio governo reconheceria em um documento de 1776.

A resolução da questão protestante marcará a inauguração de uma outra forma de intervenção estatal na esfera religiosa. Mas até aqui, o que foi visto deixa evidente que houve um período na história francesa no qual o Estado considera a identidade religiosa de seus súditos como princípio relevante de classificação social. Nessa situação, ser "reformado" trazia consigo uma série de efeitos civis. O Édito de Nantes aposta, a partir de uma política de distinção, na possibilidade 
de um equilíbrio que garanta a convivência pacífica e a lealdade geral ao monarca. Mas no século XVII ocorre uma inflexão na direção de uma política de desaparecimento, tornando cada vez mais pesado o fardo de ser "reformado", que ressurge no século seguinte sob a capa do "novo convertido". Considerada como critério de ordenação social, a religião ocupa um lugar claro em um modelo de condução política. Estamos às vésperas da Revolução de 1789 e quando olhamos para trás o que se vê é a reiteração de um projeto que procura atrelar a unidade política, cívica e nacional a uma exigência de unidade religiosa. E lembremos que isso ocorre exatamente no período em que o Estado francês, então imbuído das doutrinas absolutistas, consolida-se a partir do fortalecimento do poder central.

Vimos que a política de assimilação, ao final, extenua-se em uma tolerância de facto. O fracasso parece revelar algo sobre as dificuldades gerais de um dispositivo estatal baseado na identidade religiosa dos indivíduos, pois seu funcionamento depende de algum tipo de controle, pelo mesmo poder estatal, das instâncias às quais estão referidas as identidades religiosas. Esse controle não podia deixar de ser complicado em relação à Igreja Católica, devido à sua complexidade e ao seu peso histórico. Mas não foi menos problemático no caso do protestantismo: em um primeiro momento, o emperramento das instâncias tradicionais de regulação institucional, especialmente em função da inviabilização dos sínodos e assembléias, gerou formas bastante heterodoxas de devoção na segunda metade do século XVII; depois, o protestantismo consegue se recompor exatamente porque se decretou que ele não mais existia, levando à suspensão dos controles específicos a seu respeito. Nas duas situações, a intervenção do poder central alimentou reações por parte dos protestantes (ou de seus aliados) que sempre arriscavam tomar a via da sedição, pecha que esteve colada aos dissidentes da Igreja Católica desde sua introdução no reino de Francisco I. Nessa configuração, à politização da religião produzida pelos dispositivos estatais correspondia, muitas vezes a despeito dos posicionamentos efetivos dos fiéis, uma religião politizada. A religião que deveria sustentar o Estado poderia também ameaçá-lo.

\section{A DESPOLITIZAÇÃO DA RELIGIÃO}

Na metade do século XVIII, apesar da tolerância com que eram tratados, a situação legal dos protestantes permanecia delicada. Nos tribunais, passaram a se multiplicar os casos de heranças contestadas em

\section{4}


A Religião que a Modernidade Produz...

função da alegação de casamentos ou nascimentos ilegítimos, pois não registrados na Igreja Católica (Adams, 1991). Um novo Édito de $1787 / 1788$, sucedendo a amplas discussões que se desenrolam a partir da década de 1760, procura resolver o problema que formula nos seguintes termos: tendo seu estatuto civil vinculado à Igreja Católica, aos protestantes não restava senão recorrer a "conversões simuladas" ou comprometer a situação de seus filhos através de casamentos nulos. A solução que oferece se orienta por um foco estrito sobre a questão civil: trata-se de garantir a oficialização dos nascimentos, casamentos e óbitos de protestantes, justificada como um direito natural, através da possibilidade de registrá-los junto ao oficial de justiça local. O édito proíbe que os protestantes se constituam como grupo corporado e priva-os de certos postos públicos e docentes. Além disso, confirma que o catolicismo continua a gozar do monopólio do "culto público" e a prometer o favorecimento dos meios que propiciarão a reunião dos súditos na "antiga fé do nosso reino" (apud Wanegffelen, 1998:283-285).

O protestante voltava à nação, não mais pelo signo da distinção, mas por sua inscrição civil. O édito marca a própria laicização dos registros civis na França. Nesse movimento, os protestantes não aparecem em sua identidade religiosa particular, mas como usuários de uma alternativa oficial aberta aos "não católicos" (esta é a categoria utilizada no texto do édito). Não por acaso, no mesmo período transcorrem as negociações que vão conduzir à "emancipação" de outro grupo "não católico", os judeus. Ao contrário dos protestantes, os judeus franceses caracterizavam-se por uma certa autonomia garantida por organizações comunitárias, embora as situações variassem radicalmente dependendo da região e dos antecedentes históricos. Do ponto de vista do Estado, não havia um, mas vários estatutos jurídicos aplicáveis aos judeus do ancien régime. Duas leis, de 1790 e 1791, extinguem essa multiplicidade de regimes com o objetivo de dar plena e igual cidadania aos judeus (Raphäel, 1988a; 1988b; Graetz, 1989). No caso dos protestantes, as restrições civis ainda pendentes do Édito de 1787/1788 são eliminadas com a prorrogação da primeira Constituição, em 1791.

Em relação à questão religiosa, uma redefinição crucial ocorre entre 1789 e 1802. O primeiro momento dessa redefinição vem com a elaboração da Declaração Universal dos Direitos do Homem e do Cidadão. O projeto apresentado em julho de 1789 contém dois artigos que prosseguem na lógica da dominância católica, tomada inclusive como re- 


\section{Emerson Giumbelli}

ferência para uma certa tolerância: "A manutenção da religião exige um culto público. O respeito do culto público é portanto indispensável" (art. 17); "Todo cidadão que não perturba o culto estabelecido não deve ser inquietado" (art. 18) (apud Langlois, 1989:475). A fórmula sucumbiu por razões outras que as de conteúdo: durante as discussões que estabeleceram o texto final, decidiu-se que o catolicismo mereceria outros cuidados, mais adequados a uma lei constitucional; por enquanto, tratava-se de definir "direitos universais". Uma emenda transformou radicalmente a proposição: "Ninguém pode ser inquietado por suas opiniões nem perturbado no exercício de sua religião". Ela torna-se a base do art. 10 da Declaração, cuja redação final é a seguinte: "Ninguém deve ser inquietado por suas opiniões[,] mesmo religiosas[,] contanto que sua manifestação não perturbe a ordem pública estabelecida pela lei" (Langlois, 1989).

Três observações parecem oportunas. Baubérot tem razão quando afirma que "passou-se de uma religião pública exclusiva à possibilidade de afirmar suas convicções religiosas" (1993:87). Ainda que se possa discutir sobre a conotação assumida pela partícula "mesmo", as implicações do artigo são individualistas e pluralistas (Langlois, 1989). Temos aí um dos fundamentos da noção de "liberdade religiosa", sob um modo que considera a adesão religiosa desvencilhada de pertencimentos confessionais específicos. Mas, isso reconhecido, note-se que a distinção entre "opiniões" e "manifestação" reintroduz a antiga dicotomia entre "consciência" e "culto", afastados entre si pelos limites a que uma e outro estão sujeitos. Finalmente, a formulação incorpora a noção de "ordem pública", que vem repor uma dimensão restritiva, anteriormente presente na forma de um "culto estabelecido". O mais importante a destacar aqui é exatamente a permanência desse princípio de restrição, que acarreta um vínculo irremovível entre a vivência religiosa, agora definida em termos genéricos, e o Estado, guardião e representante da "ordem pública" (Koubi, 1993). Apesar de se apresentar sob definições que posteriormente poderiam ser vistas com implicações efetivamente revolucionárias, há portanto nesse artigo elementos de continuidade com o passado.

Para o catolicismo, sabemos o que a revolução reserva - a Constituição Civil do Clero (1790), que pretende transformar a Igreja em agente público, seus membros e suas instituições postos a serviço do Estado que é responsável por sua manutenção. Esse projeto de uma "igreja nacional", que se prolonga com os "cultos revolucionários", é en-

\section{6}


cerrado com a Constituição de 1795, que veda a manutenção de cultos pelo Estado (Langlois, 1989; Fauchois, 1988). Entretanto, ele acaba, a seguir, ressuscitado sob nova forma, demonstrando a existência de um segundo vetor na relação entre religião e Estado na França pós-revolucionária. O Estado, acabamos de ver, intervém como guardião da "ordem pública" à qual deve se adequar a pluralidade teoricamente infinita das experiências religiosas; mas ele intervém também para organizar as próprias instituições onde essas experiências majoritariamente se inscrevem. Ora, a França adentra o século XIX, comandada por Napoleão Bonaparte, com o regime dos quatro cultos reconhecidos, que compreende o catolicismo, o calvinismo, o luteranismo e o judaísmo ${ }^{6}$. A hegemonia católica é admitida ${ }^{7}$, mas sem dúvida o sistema consagra um pluralismo limitado, através do qual se combina a garantia de liberdade religiosa sob os limites da "ordem pública" e a existência de "cultos" reconhecidos pelo Estado (Langlois, 1989).

Esse reconhecimento implicava algum tipo de coordenação entre o poder central e as estruturas eclesiásticas de cada um dos quatro cultos: as contribuições materiais por parte do primeiro são compensadas pela abertura a intervenções no seio das segundas. No caso do catolicismo, a regulamentação de uma nova concordata, de 1801, com a Santa Sé procura estabelecer uma série de prerrogativas sobre as atividades dos eclesiásticos católicos e ratificar uma teologia favorável à supremacia imperial. Ou seja, ao invés da Igreja galicana estabelecida com a Constituição Civil do Clero, uma Igreja romana controlada de perto pelas autoridades francesas ${ }^{8}$. As transformações no funcionamento das igrejas reformada e luterana e do culto judaico são ainda mais explícitas, dada sua originalidade. Durante o século XVIII, os judeus constituíam "nações" em torno de comunidades dispersas e munidas, em diferentes graus, de poder judiciário e fiscal sobre seus membros. Depois de serem "emancipados" com a Revolução, haverá uma intervenção clara no sentido de reorganizar e controlar suas instituições eclesiais. Entre 1806 e 1808 tomam-se providências (articuladas a uma concepção individualista e privatizante da religião) que, a partir de iniciativas estatais, vão conferir ao culto judaico uma organização local (consistórios) composta por rabinos e notáveis, nacionalmente unificada em estruturas centralizadas e representantes gerais (Graetz, 1989). 


\section{Emerson Giumbelli}

Quanto aos protestantes, a reforma napoleônica introduziu novas formas de organização para reformados e luteranos, com efeitos distintos nos dois casos (Encrevé, 1985). Para os reformados, um sistema baseado em assembléias locais a partir das quais eram eleitos os componentes de sínodos representativos transforma-se com a inserção de uma outra unidade organizativa, o consistório. Este representou a criação de uma instância totalmente nova, já que quase sempre abrangia várias igrejas locais (que se tornaram oficiosas) e dificultava as reuniões sinodais (sujeitas à permissão governamental). $\mathrm{O}$ consistório passa a ser o ponto de apoio para o controle das autoridades. Para os luteranos, que adotavam uma multiplicidade de sistemas de organização das comunidades de culto, esse controle ocorre de outra forma. Em vez das paróquias, a célula básica passa a ser o consistório. Acima dele se colocam as inspeções e um diretório. Antes das reformas, havia os consistórios, mas eles constituíam não a célula básica, e sim instâncias superiores às paróquias, formando sistemas sem vínculo formal entre si. Depois, tem-se um sistema unificado, integrando consistórios/inspeções/diretório, sendo que as duas últimas instâncias contavam com membros nomeados pelo governo.

Esse sistema de "cultos reconhecidos" nem sempre funcionou como projetado nem esteve a salvo de reações por parte das próprias comunidades religiosas. Para os objetivos da análise aqui empreendida, porém, o ponto decisivo consiste na manutenção de uma forma de atrelamento entre o Estado e a religião. Lembremos, primeiro, que o sistema convive com a noção de "ordem pública", encarnada pelo Estado, que qualifica o modo de "liberdade religiosa" inventado pela Revolução. No mecanismo de reconhecimento dos "cultos" essa presença é bem menos sutil, expressando-se em suporte monetário e dispositivos de intervenção no funcionamento eclesial. Entretanto, quando se compara esse sistema com as formas anteriores de atrelamento entre o Estado e a religião, o contraste é evidente. Passa-se de dispositivos que atingem os indivíduos para outros nos quais o foco recai sobre instituições confessionais. O principal efeito dessa transformação consiste em retirar a religião do quadro de condições que a vinculam a exigências políticas e cívicas. Em outras palavras, trata-se de uma forma de despolitizar a religião, rompendo-se as implicações políticas e cívicas de se considerar "católico", "protestante" ou "judeu". Mas isso não significa que o Estado se desinteresse da "religião"; a instauração de uma certa forma de autonomia para a esfera

\section{8}


religiosa é acompanhada da montagem de um sistema de controles sobre as instituições eclesiais.

\section{O RECONHECIMENTO DA RELIGIÃO EM UMA REPÚBLICA LAICA}

Existem muitos sinais evidentes na França atual de que o Estado mantém relação com questões, instituições e representantes religiosos. No Ministério do Interior, por exemplo, encontra-se, junto ao próprio ministro, um "conselheiro para assuntos religiosos"; e uma de suas repartições carrega a designação que se pode traduzir por "setor de cultos". Além disso, vários aparatos estatais contam entre suas atribuições com responsabilidades que envolvem diretamente o domínio religioso. É o caso da previdência social para os ministros de culto, dos programas religiosos nas redes estatais de rádio e TV, da participação de religiosos em comissões ou cerimônias oficiais. E, apesar de não mais consistir no regime dominante, o sistema dos "cultos reconhecidos", por razões históricas, em algumas regiões ainda possui validade, acrescentado de certas modificações (Boyer, 1993; Bedouelle e Costa, 1998). Essas características, longe de constituírem excrescências, apontam para o que se deve considerar como o fulcro do regime atual de relações entre Estado e religião, mesmo estando ele identificado pela noção de "separação": uma nova modalidade de reconhecimento, em função da qual o fundamental passam a ser os mecanismos que operam a delimitação de um domínio social específico.

O sistema de "cultos reconhecidos" tem seu termo em 1905, com a "lei de separação" ", que veda ao Estado "reconhecer", "assalariar" e "subvencionar" qualquer culto, e procura reforçar as garantias quanto à "liberdade religiosa" dos indivíduos, prevendo, por exemplo, a presença de capelães em estabelecimentos públicos. Nesse sentido, a nova regulamentação aprofunda um vetor de laicização, bastante nítido especialmente a partir da III República (1871), quando, entre outras medidas, o ensino religioso é retirado do currículo escolar e os cemitérios são secularizados. Esse vetor reaparece na inscrição do princípio da laicidade nas duas mais recentes constituições francesas (1946 e 1958). Mas há na lei de 1905 também uma outra dimensão, igualmente significativa. Reiterando a validade da noção de "ordem pública" como marco limitador, essa lei, não se endereçando a grupos religiosos específicos ou nomeados, prescreve os quadros jurídicos aos quais se deve adequar toda e qualquer confissão religiosa. Para isso, é criada a association cultuelle, um tipo especial de associação, 


\section{Emerson Giumbelli}

destinado a cumprir finalidades exclusivamente religiosas. Assim, a instituição de uma entidade associativa própria torna-se a contrapartida de uma operação que pretende desvencilhar o Estado das questões religiosas. A articulação entre essas disposições prolonga o atrelamento entre Estado e religião que, agora, ocorre não mais sob a forma de um sistema fechado e nominal, estabelecido em torno dos "quatro cultos", mas pela definição jurídica de um domínio específico, povoado por um número teoricamente ilimitado de elementos, identificado como "religioso".

Vê-se comumente na lei de 1905 o ponto final de uma história, com suas idas e vindas, que se consumaria tanto na autonomização da política quanto na da religião. Doravante, o Estado não estaria mais associado a nenhuma religião ou instituições religiosas; estas, por sua vez, estariam finalmente livres de qualquer intervenção estatal. Sugiro aqui uma outra interpretação, que procura ver na laicização que se opera nesse momento o modo pelo qual se reconfigura o interesse do Estado pela "religião". É verdade que a lei de 1905, por intermédio da association cultuelle, pretende criar um tipo de organização que se adequaria a qualquer religião e que não possuiria vínculos diretos com o Estado. No entanto, a "separação" que ela institui retira suas condições de possibilidade da situação criada pelas intervenções que caracterizavam o período anterior. É revelador que essa lei não se preocupe em definir o que seja "religião". Supunha-se, pois, uma coordenação natural entre as formas de regulação imprimidas pelas várias instâncias confessionais e as formas de reconhecimento jurídico proporcionadas pelo Estado, assim como uma congruência automática entre a auto-identificação das instituições enquanto "religiosas" e a atribuição dessa identidade de acordo com a legislação estatal. Sendo desse modo, era de se esperar que as situações colocadas por outro contexto social e histórico levassem esse regime a se expressar através de outros mecanismos e dispositivos.

Durante o século XX, mantém-se, em termos sociais e populacionais, a dominância católica, enquanto, grosso modo, se observa no mundo institucional protestante e judaico uma acomodação ao regime das associations cultuelles. Embora não deixem de atingir esse universo tradicional, as principais transformações no campo religioso francês vêm associadas a outros rótulos e fenômenos. Refiro-me ao "islamismo" e às "seitas"10. Quanto ao primeiro, consolida-se na cena social nos anos 1970, quando ocorre uma mudança no padrão imigratório. 
A Religião que a Modernidade Produz...

Desde então, os imigrantes vindos majoritariamente de países muçulmanos tendem a se estabelecer em grupos familiares, abandonando o projeto de retorno aos locais de origem. Apontado como a segunda maior religião na França, o "islamismo" constitui na verdade o rótulo para um conjunto heteróclito que abriga formas variadas de vida associativa e devocional. Eis aí, aliás, uma das características que o tornam problemático do ponto de vista de posicionamentos bem disseminados na sociedade francesa. Lamenta-se, a propósito do "islamismo", a ausência ou a fragilidade de estruturas eclesiásticas análogas às de outras "religiões tradicionais" e a inexistência de instâncias representativas sólidas em sua legitimidade. Além disso, são comuns diagnósticos que detectam no "islamismo" francês tendências "fundamentalistas", manifestas seja em atividades políticas, seja em relações de gênero e socialização infantil. No plano político, aliás, os temores ressonam acusações que pesaram no passado sobre os "huguenotes", já que se concentram sobre ações terroristas e a influência e o financiamento de governos estrangeiros.

As "seitas", por sua vez, remetem a uma designação aplicada a uma miríade de grupos de natureza bastante heterogênea e que carregam uma conotação claramente acusatória. Desde a década de 1970, o termo deixou de freqüentar a polêmica estritamente religiosa para se referir a grupos cujas ações colocariam em risco indivíduos e sociedade - uns ameaçados pela "desestabilização mental" que mina o livrearbítrio, a outra assaltada em suas instituições-chave por manobras de "infiltração" que abalam a democracia. As "seitas", assim definidas, tornaram-se uma questão pública, pela qual se interessam não apenas igrejas tradicionais, mas também a mídia e o Estado. Reportagens, documentários, livros, em enorme quantidade, consagraram os jornalistas como protagonistas importantes na caracterização das "seitas". Duas comissões de inquérito já foram dedicadas ao tema no Parlamento francês, em 1995 e 1999, na esteira de debates jurídicos de significativa densidade. Mas se a categoria "seita" conquistou tal estatuto e importância públicos, isso se deve em grande parte ao trabalho de associações que pretendem desmascarar suas "artimanhas" e defender suas "vítimas". Por intermédio do recebimento de denúncias, da sistematização de informações, da ação junto à mídia e ao Estado, essas associações constituem a peça principal de um dispositivo que visa a identificação e a vigilância de "seitas". Sem estar circunscrito a um único domínio social, o acionamento dessa categoria 
acusatória parece servir como um sintoma de deficiências e insuficiências dos mecanismos regulatórios nas mais diversas esferas, inclusive a religiosa.

Os elementos que compõem as controvérsias e apreensões que cercam o "islamismo" e as "seitas" se mostram bastante interessantes pelo fato de revelarem, por parte das autoridades francesas, uma postura que confirma o reconhecimento estatal da "religião". No caso do "islamismo", isso fica explícito, para usar os termos de Frégosi (1996), na "gestão policial" com que o assunto é tratado. Mas prolonga-se por movimentos que são até mais significativos, embora menos dramáticos. De um lado, uma série de medidas, de caráter essencialmente administrativo, procura estender aos muçulmanos possibilidades e prerrogativas já desfrutadas por outras religiões: dispensas trabalhistas, alimentos apropriados em refeitórios de estabelecimentos coletivos, espaço em cemitérios, regulamentação de procedimentos e habilitação de especialistas rituais. Condições que a princípio estariam ligadas exclusivamente à garantia de "liberdade religiosa" passam a indicar também um vínculo entre Estado e confissões religiosas. De outro lado, ocorrem intervenções, mais ou menos ostensivas, no sentido de prover o islamismo francês de uma instituição capaz, a um só tempo, de aglutinar e organizar o universo associativo religioso e de se apresentar como interlocutor avalizado junto aos poderes públicos. Em suma, o reconhecimento do islamismo, que se opera pelo esforço de sua isonomização com as "religiões tradicionais", tem como contrapartida a exigência, eventualmente transformada em intervenção, de seu enquadramento em instituições sintonizadas com o Estado. Não é sem razão que uma autora se refere a esse processo como uma tentativa de "consistorialização" do islamismo (Hervieu-Léger, 1999), pois a semelhança com o que ocorreu no início do século XIX envolvendo protestantismo e judaísmo não é ilusória.

Tratando-se das "seitas", nota-se na última década a constituição de mecanismos específicos de acompanhamento e intervenção no plano das esferas executivas do Estado francês. A demonstração mais evidente disso é a criação, em 1996, do Observatório Interministerial sobre as Seitas, sucedido em 1998 pela Missão Interministerial de Luta contra as Seitas, organismos ligados ao primeiro-ministro. Em torno dessas instâncias ou mesmo ao largo delas, desenvolveu-se uma série de medidas destinadas igualmente a alvejar o "problema das seitas", muitas das quais permitem também aqui se referir a uma "gestão po- 
A Religião que a Modernidade Produz...

licial": estatísticas e compilação de informações, campanhas de esclarecimento, estímulo ao enquadramento judicial, alijamento das fontes de auxílio ou habilitação oficial. Um dos pontos que concentram atenção pública é exatamente a concessão do estatuto de association cultuelle, que, embora envolva a conquista de certas vantagens materiais (isenções tributárias e capacidades jurídicas), coloca em jogo principalmente uma questão de legitimação social. Não cabe entrar em detalhes aqui nas condições e nos procedimentos relacionados à aquisição desse estatuto. $O$ fato fundamental reside em que autoridades administrativas e fiscais, diante do assédio de grupos publicamente tidos como "seitas" mas que reivindicam serem "religiosos", procuram impedi-los de utilizar para si a designação association cultuelle. Ao fazê-lo, transformaram decisivamente a natureza dessa figura jurídica. A lei original das associations cultuelles não previa nenhum mecanismo de autorização do título; a presença das "seitas" trouxe consigo a invenção de tal procedimento, que implica um aval inequívoco por parte de aparatos estatais acerca da qualidade "religiosa" de certas associações. Mas também seria correto afirmar que o contexto atual não traz senão as condições que obrigam a explicitar o que em 1905 permanecia como algo tácito.

Uma maneira de relacionar as duas situações aqui enfocadas consiste em apontar para dois movimentos opostos que, entretanto, envolvem os mesmos termos: enquanto a postura assumida diante do "islamismo" visa convertê-lo em uma "religião", essa condição é negada através das medidas tomadas a propósito das "seitas". Ambas as situações revelam as formas contemporâneas que confirmam a relevância social da categoria "religião" na perspectiva do Estado francês e os mecanismos através dos quais esta relevância se expressa. Que elas se inscrevam no quadro de um regime orientado pela noção de "laicidade" não deixa de ser curioso. Ocorre que os mesmos mecanismos jurídicos que no início do século permitiam falar em "separação" funcionam hoje no sentido de precisar e explicitar os vínculos que atrelam as "religiões" ao Estado. Embora a "laicidade" — considerando seja seu significado literal, seja as interpretações dominantes que sobre ela existem - sugira uma relação negativa do Estado com o "religioso", os mecanismos e dispositivos sobre os quais se assenta remetem para o inverso disso. Ou seja, a "laicidade" não constituiria senão uma forma específica de reconhecimento da religião por um Estado moderno. 
As análises aqui apresentadas possuem certas implicações para a discussão de uma problemática que está no fulcro das relações entre "modernidade" e "religião", a saber, o paradigma da secularização ${ }^{11}$. Segundo este paradigma, com a "modernidade" ocorreria um retraimento progressivo do espaço ocupado pela "religião" e das lógicas por ela orientadas. Muito raramente o argumento chegou ao ponto de profetizar o desaparecimento da religião; e nem a diminuição de crenças e práticas religiosas, ainda que esperada, tornou-se o indicador fundamental para corroborar a tese da secularização. Na verdade, o ponto crucial desse paradigma reside na idéia de um processo de diferenciação estrutural da sociedade, a partir do qual a religião deixa de ser uma instância encompassadora e totalizante para se tornar um domínio específico com seus próprios limites e regras de funcionamento. Teríamos aí a base sociológica para a operação jurídica de separação entre Estado e igrejas. Note-se que a idéia de retraimento da religião não possui nada de contraditório com argumentos dedicados a apontar as raízes religiosas desse processo - como seria o caso da tese weberiana exposta em A Ética Protestante e o Espírito do Capitalismo. A despeito das possíveis raízes religiosas, a questão decisiva, observada em um plano sincrônico, pauta-se no que seria a lógica geral de uma "sociedade moderna" e nas suas conseqüências para a "religião".

É inegável que existam diversas evidências históricas e sociológicas a corroborar a idéia de um retraimento do religioso na modernidade. Mas as mesmas evidências sugerem a necessidade de introduzir nessa idéia certas modulações. Por exemplo, a variedade das situações religiosas, mesmo considerando apenas as regiões mais tocadas pela "modernidade", desaconselha interpretações teleológicas do paradigma da secularização. Não façamos dele uma nova filosofia da história. Outra dimensão a ser lembrada é a dos discursos, uma vez que a limitação que a "religião" na "modernidade" tendeu a sofrer desenrola-se em meio a um conjunto de projetos e de formulações, enunciados por determinados agentes sociais, que incorpora ambos os termos como categorias discursivas. Esses discursos, por si sós, não explicam nem conduzem um processo social de dimensões bem mais amplas, mas é preciso admitir que eles o conformam e lhe conferem certos significados, influenciando os modos tomados pela secularização. Portanto, torna-se fundamental enfocar a problemática da relação entre "modernidade" e "religião" no interior de um quadro que 
contemple tanto condições históricas específicas quanto a presença e diversidade de discursos acerca daquela relação. Além disso, é preciso reconhecer que o fato de a "religião" ter deixado de ser a instância central da sociedade não significa que tenha perdido importância ou relevância social na atualidade.

Nessa direção, trago um ponto que, creio, assume feições mais comprometedoras para o paradigma da secularização, pois ele parece padecer de uma ilusão de enormes conseqüências: a suposição de que a "religião" não muda de natureza antes e depois da "modernidade". A transformação marcada pela "modernidade" é de ordem, por assim dizer, topológica. Antes, a "religião" ocupava o centro ou a totalidade do terreno social; depois, ela está reduzida a um domínio específico e de menor importância diante de outros; mas aquilo que a define, seja o que for, continua o mesmo. Sugerir o contrário, isto é, que o período com o qual se identifica a "modernidade" no Ocidente marca a invenção de um novo discurso sobre a "religião", leva-nos a ver a questão sob outro ângulo. Então, levanta-se logo um dilema para o paradigma da secularização: por um lado, ele parece estar condenado, uma vez que trata necessariamente de um retraimento, a engendrar uma relação negativa entre "modernidade" e "religião"; por outro, quando não trata da "modernidade" mas do que estaria "antes" ou "fora" dela, ele sofre permanentemente do problema de projetar sobre o passado ou o alhures uma definição de "religião" histórica e geograficamente circunscrita. Uma maneira de contornar esse dilema é exatamente reconhecer que a "modernidade" forja aquilo que pretende destruir ou limitar. Isso permite tanto buscar outros modos para tratar da "religião" que está antes ou fora da "modernidade", quanto encontrar aspectos que apontam para uma relação positiva entre "modernidade" e "religião".

Procurei explorar essas possibilidades ao me debruçar sobre certas facetas da história da França, privilegiando a dimensão política. $\mathrm{O}$ modo com que o Estado francês resolve os conflitos envolvendo catolicismo e protestantismo no século XVI, consagrando a "religião" como princípio de ordenação social, concede-lhe um lugar e um estatuto que não detinha nem mesmo na dinâmica das tais "guerras de religião". O que se observa desde então são formas sucessivas e mutantes de reconhecimento da "religião" pelo Estado. Primeiro, através do atrelamento da identidade religiosa dos indivíduos às capacidades cívicas e políticas; depois, pelo controle direto sobre as principais es- 


\section{Emerson Giumbelli}

truturas institucionais religiosas; enfim, através da delimitação de um domínio específico para a religião com o pressuposto ou a exigência de que esse domínio se organize segundo critérios convergentes aos adotados pelo Estado em relação à totalidade do terreno social. $\mathrm{O}$ foco da análise recai não sobre modelos macrossociais de relação Estado/Igreja ("união" /"separação"), mas sobre os dispositivos e mecanismos por intermédio dos quais se dá concretamente aquela operação de reconhecimento. O que torna a França um caso de particular interesse, vale repetir, é - além de sua relação com a "modernidade" não estar jamais em questão - o fato de que, lá, esse reconhecimento da "religião" pelo Estado tende a obscurecer-se na sombra da noção de "laicidade". Mas, ainda que privilegiado, é realmente apenas um caso, cuja singularidade resulta não de qualidades essenciais, mas do produto histórico da ação de fatores e vetores que existem também em outras realidades. Eis por que o modo de problematização e as opções analíticas aqui explorados podem ser pertinentes diante de outras situações nacionais.

(Recebido para publicação em maio de 2001)

\section{NOTAS}

1. No campo da antropologia, pode-se destacar o texto de Dumont (1971) e, especialmente, o de Asad (1993). No campo da história das religiões, o livro de Smith (1991) foi o pioneiro na mesma direção; outras contribuições relevantes se encontram em Despland (1979), Dubuisson (1998) e Harrison (1990).

2. Baseio-me nas narrativas expostas por Holt (1995), Livet (1996) e Vernard (1988). A abordagem adotada pretende levar às últimas conseqüências a observação contida na última referência: “[...] os fatores propriamente religiosos da crise são às vezes difíceis de desentranhar dos processos políticos e sociais, sem esquecer a conjuntura econômica" (Vernard, 1988:249). Os mesmos textos, acrescidos do de Lecler (1955), serviram para a elaboração do contexto anterior e contemporâneo às “guerras de religião".

3. Afirma o preâmbulo: "[...] e se não lhe [a Deus] satisfaz permitir que ocorra por enquanto em uma mesma e única forma de religião, que ao menos seja sob uma só intenção" (apud Wanegffelen, 1998:261). Holt (1995:163) é enfático em tratar o Édito de Nantes no interior do princípio "un roi, une foi, une loi". Ricoeur (1995:172), no

\section{6}

Revista Dados 
A Religião que a Modernidade Produz...

mesmo sentido, refere-se ao édito como uma saída pragmática dentro da lógica da unidade.

4. Wanegffelen (1998:55) refere-se a um catolicismo galicano e "não confessional". Durante o reinado de Henrique IV, cogitava-se ainda na realização de um concílio nacional. O rei chegou a promover em 1600 uma discussão teológica entre um católico e um reformado acerca da eucaristia. Holt (1995:169-171) refere-se a várias evidências que demonstram os esforços de Henrique IV no sentido de trazer os protestantes de volta a uma única igreja.

5. As fontes que me auxiliaram na análise da questão protestante após o Édito de Nantes foram Holt (1995), Garrison (1985) e Adams (1991).

6. No caso do catolicismo, a relação foi estipulada por uma concordata com a Santa Sé, $1801 / 1802$. No caso das demais religiões, leis específicas foram erigidas a partir de 1802.

7. Na Constituição de 1814, a religião católica é proclamada "religião do Estado"; na de 1830 é reconhecida a religião da "maioria dos franceses" (apud Wanegffelen, 1998:311-312).

8. Sobre a concordata de 1801 e as possibilidades de intervenção estatal, ver Boyer (1993), Poulat (1987) e Bedouelle e Costa (1998). Note-se que durante o século XIX, em geral, as congregações estiveram sujeitas a exigências de autorização para funcionamento.

9. Lei de 9/12/1905 e decreto de 16/3/1906. Esta lei foi modificada por diversas disposições posteriores (ver publicação do Journal Officiel de la République Française, 1996).

10. Sobre a situação atual do islamismo na França, baseei-me em Pierré-Caps (1990), Frégosi (1996) e Basdevant-Gaudemet (1996). O problema das seitas é objeto de minha tese de doutorado (Giumbelli, 2000) - uma comparação entre o Brasil e a França a propósito de polêmicas recentes envolvendo o lugar e o estatuto da religião nas duas sociedades.

11. A idéia de paradigma aplicada às teses da secularização é emprestada a Tschannen (1992). Trata-se de um abrangente estudo sobre os argumentos e os autores que estariam associados àquele paradigma. $\mathrm{O}$ volume e a diversidade desses argumentos e referências tornam impossível, nos limites dos propósitos deste artigo, um tratamento adequado do tema. 


\section{Emerson Giumbelli}

\section{REFERÊNCIAS BIBLIOGRÁFICAS}

ADAMS, Geoffrey. (1991), The Huguenots and French Opinion 1685-1787. Waterloo, Wilfrid Laurier University Press.

ASAD, Talal. (1993), Genealogies of Religion. Discipline and Reasons of Power in Christianity and Islam. Baltimore, The Johns Hopkins University Press.

BASDEVANT-GAUDEMET, Brigitte. (1996), “Le Statut Juridique de l'Islam en France". Revue du Droit Public, março/abril, pp. 355-384.

BAUBÉROT, Jean. (1993), "Estratégias da Liberdade”, in C. Sahel (org.), A Tolerância. Porto Alegre, L\&PM.

BEDOUELLE, Guy e COSTA, Jean-Paul. (1998), Les Laïcités à la Française. Paris, PUF.

BOYER, Alain. (1993), Le Droit des Religions en France. Paris, PUF.

CHRISTIN, Olivier. (1997), La Paix de Religion. L'Automisation de la Raison Politique au XVIe Siècle. Paris, Seuil.

DESPLAND, Michel. (1979), La Religion en Occident. Montreal, FIDES.

DUBUISSON, Daniel. (1998), L'Occident et la Religion. Bruxelas, Éditions Complexe.

DUMONT, Louis. (1971), “Religion, Politics, and Society in the Individualistic Universe". Proceedings of the Royal Anthropological Institute for 1970.

ENCREVÉ, André. (1985), Les Protestants en France de 1800 à nos Jours. Histoire d'une Reintégration. Paris, Stock.

FAUCHOIS, Yann. (1988), “Révolution Française, Religion et Logique de l'État". Archives des Sciences Sociales des Religions, vol. 66, nำ1, pp. 9-24.

FRÉGOSI, Franck. (1996), “Les Problèmes Liés à l'Organisation de la Religion Musulmane en France". Revue de Droit Canonique, vol. 46, no 2, pp. 215-238.

GARRISON, Janine. (1985), L'Édit de Nantes et sa Révocation. Paris, Seuil.

GIUMBELLI, Emerson. (2000), O Fim da Religião: Controvérsias acerca das "Seitas" e da "Liberdade Religiosa" no Brasil e na França. Tese de Doutorado, PPGAS/MN/UFRJ.

GRAETZ, Michael. (1989), “De l'Emiettement à l’Unité Jacobine: La Révolution et l'Empire ont Provoqué une Nouvelle Organisation des Juifs de France", in Les Juifs en France au XIXeme Siècle. Paris, Seuil.

HARRISON, Peter. (1990), "Religion" and the Religions in the English Enlightenment. Cambridge, Cambridge University Press.

HERVIEU-LÉGER, Danièle. (1999), Le Pèlerin et le Converti. La Religion en Mouvement. Paris, Flammarion.

HOLT, Mack. (1995), The French Wars of Religion, 1562-1629. Cambridge, Cambridge University Press.

JOURNAL OFFICIEL DE LA RÉPUBLIQUE FRANÇAISE. (1996) [1991], Cultes et Associations Cultuelles; Congrégations et Collectivités Religieuses. JORF, noำ 1524.

\section{8}

Revista Dados 


\section{A Religião que a Modernidade Produz...}

KOUBI, Geneviève. (1993), “Article 10", in D. Conac e Toboul (eds.), Déclaration des Droits de l'Homme et du Citoyen de 1789. Paris, Economica.

LANGLOIS, Claude. (1989), “Religion, Culte ou Opinion Religieuse: La Politique des Révolutionnaires". Revue Française de Sociologie, vol. XXX, pp. 471-496.

LECLER, Joseph. (1955), Histoire de la Tolérance au Siècle de la Réforme. Paris, Éditions Montaigne.

LIVET, Georges. (1996), Les Guerres de Religion. Paris, PUF.

PIERRÉ-CAPS, Stéphane. (1990), “Les 'Nouveaux Cultes' et le Droit Public”. Revue du Droit Publique, vol. 4, pp. 1073-1119.

POULAT, Émile. (1987), Liberté, Laïcité: La Guerre des Deux France et le Principe de la Modernité. Paris, CERF/Cujas.

RAPHÄEL, Freddy. (1988a), “Le Judaïsme, Religion Française Reconnue”, in R. Rémond e J. Le Goff (eds.), Histoire de la France Religieuse. Paris, Seuil.

_. (1988b), “Les Juifs de l'Ancien Régime”, in R. Rémond e J. Le Goff (eds.), Histoire de la France Religieuse. Paris, Seuil.

RICOEUR, Paul. (1995), “Tolerância, Intolerância, Intolerável”, in Em Torno ao Político. São Paulo, Loyola.

SMITH, Wilfred. (1991) [1962], The Meaning and the End of Religion. Minneapolis, Fortress Press.

TSCHANNEN, Olivier. (1992), Les Théories de la Sécularisation. Genebra, Droz.

VERNARD, Marc. (1988), “La Grande Cassure”, in R. Rémond e J. Le Goff (eds.), Histoire de la France Religieuse. Paris, Seuil, vol. 2.

WANEGFFELEN, Thierry. (1998), L'Édit de Nantes. Une Histoire Européenne de la Tolérance (XVIe-XXe Siècle). Paris, Le Livre de Poche. 


\title{
Emerson Giumbelli
}

\author{
ABSTRACT \\ The Religion that Modernity Produces: On the History of Religious \\ Policy in France
}

This article discusses several aspects of the history of religious policy in France, focusing on realities from the 16th to 20th centuries involving the ways by which the state deals with "religion". The objective is to show that far from simply being overlooked, "religion" takes on meanings that make it a significant criterion for social ordering from the state perspective. One can thus affirm that the French state has promoted several successive forms of recognizing religious identities. French history appears here in light of a more general discussion on the place and statute of religion in modernity. Reflecting on certain points in the "secularization thesis", the article concludes by highlighting aspects that indicate a positive relationship between modernity and religion.

Key words: religion; modernity; secularization; France; laity

\section{RÉSUMÉ \\ La Religion Produite par la Modernité: Histoire de la Politique Religieuse en France}

Dans ce texte, on étudie des aspects de l'histoire de la politique religieuse en France en distinguant des faits qui ont eu lieu entre les $X V I^{\mathrm{e}}$ et $\mathrm{XX}$ e siècles et qui comprennent des façons selon lesquelles l'État considère la "religion". Son but est de montrer que, plutôt que d'être tout simplement discréditée, la "religion" prend des sens qui en font un critère significatif d'organisation sociale selon l'État. Il est donc permis d'affirmer que l'État français crée plusieurs formes successives de reconnaissance des identités religieuses. L'histoire française sert ici d'élément pour une discussion plus large sur la place et le statut de la religion dans la modernité. Après une réflexion sur quelques aspects de la "thèse de la sécularisation", on fait ressortir en conclusion certains points qui indiquent un rapport positif entre modernité et religion.

Mots-clé: religion; modernité; sécularisation; France; laïcité 